\title{
НОВЫЕ ДАННЫЕ О ПОГРАНИЧНЫХ ВЕРХНЕЮРСКИХ-НИЖНЕМЕЛОВЫХ ОБРАЗОВАНИЯХ НА ВОСТОКЕ СИБИРСКОЙ ПЛАТФОРМЫ
}

\author{
В. С. Гриненко ${ }^{1}$, А. В. Костин ${ }^{1}$, А. И. Киричкова ${ }^{2}$, М. С. Желонкина ${ }^{1}$ \\ ${ }^{1}$ Институт геологии алмаза и благородных металлов, г. Якутск \\ ${ }^{2}$ Всероссийский нефтяной научно-исследовательский \\ геолого-разведочный институт, г. Санкт-Петербург
}

Поступила в редакцию 28 мая 2018 г.

\begin{abstract}
Аннотация: пограничные образования верхней юры-нижнего мела (граница лаптевского и китчанского подкомплексов верхоянского терригенного комплекса) на востоке Сибирской платформы и в её складчатом обрамлении изучены в естественных разрезах - в бассейнах рек Вилюй, Лена и Алдан, а на закрытых территориях - по керну глубоких скважин на нефть и газ. В Вилюйской синеклизе, в коренном осадочном терригенном континентальном разрезе верхней юры, на границе с континентальным терригенным нижним мелом, впервые диагностированы вулканогенныле породы. Позднеюрский возраст вулканогенных пород установлен по многочисленным (еще не опубликованным) находкам в них листовой флоры, характерной для бергеинской свить Вилюйской синеклизы и Предверхоянского краевого прогиба. В зоне перехода «Сибирская платформа Верхояно-Кольмская складчатая область» новый разрез кровли верхней юры с вулканогенными породами скоррелирован среди опорных верхнеюрских разрезов платформы на основе региональных фитостратиграфических горизонтов Сибири. Выполненные исследования позволяют вовлечь в стратификацию Восточно-Сибирского осадочного палеобассейна на равных условиях разнофациальные (как морские терригенные, так и континентальные терригенньле и осадочновулканогеннье) образования, при этом, широко использовать в иелях корреляции по западной периферии Верхояно-Кольмской складчатой области установленные и прослеженные в юре и мелу верхоянского терригенного комплекса региональные стратиграфические и фитостратиграфические горизонты Средней Сибири.
\end{abstract}

Ключевые слова: Сибирская платформа, Вилюйская синеклиза, Предверхоянский краевой прогиб, верхняя юра, нижний мел, региональные горизонты, верхоянский терригенный комплекс, лаптевский, китчанский подкомплексы, стратифицированные подразделения (свиты, серии), континентальные и осадочно-вулканогенные породы.

\section{NEW DATA ON THE UPPER JURASSIC - LOWER CRETACEOUS ROCKS IN THE EASTERN SIBERIAN PLATFORM}

\begin{abstract}
Upper Jurassic - Lower Cretaceous boundary rocks (Laptev and Kitchan subcomplexes of the Verkhoyansk terrigenous complex) within the eastern Siberian platform and its folded framing were studied both from natural exposures in the river basins of Vilyui, Lena and Aldan and from deep horizons using samples obtained by core drilling. In the Vilyui syneclise, volcanogenic rocks were first recognized in the Upper Jurassic section of primary sedimentary terrigenous continental rocks at the boundary with the Lower Cretaceous continental terrigenous deposits. The age of the volcanogenic rocks was determined as Late Jurassic based on numerous (yet unpublished) finds of leaf flora characteristic of the Berge Formation of the Vilyui syneclise and Priverkhoyansk foredeep. In the transition zone between the Siberian platform and the Verkhoyansk-Kolyma folded region, the new section with volcanogenic rocks was correlated with the key Upper Jurassic sections of the Siberian platform on the basis of regional phytostratigraphic horizons of Siberia. The performed studies permit involvement (on equal terms) of differentfacies (marine terrigenous, continental terrigenous, and sedimentary-volcanogenic rocks) info stratification of the East Siberian sedimentary paleobasin. This requires extensive use, at the western periphery of the Verkhoyansk-Kolyma folded region, of regional stratigraphic and phytostratigraphic horizons of Siberia identified and traced in the Jurassic and Cretaceous of the Verkhoyansk terrigenous complex.
\end{abstract}


Key words: Siberian platform, Vilyui syneclise, Priverkhoyansk foredeep, Upper Jurassic, Lower Cretaceous, regional horizon, Verkhoyansk terrigenous complex, Laptev and Kitchan subcomplexes, stratified division (formation, series), continental and sedimentary-volcanogenic rocks.

\section{Введение}

Изучение геологии Якутии начато более двух веков назад русскими рудознатцами (Афанасий Метенев и другие), указавшими на находки в Верхоянском хребте свинцовых и медных руд [1]. Первые письменные сведения о нерудных месторождениях на востоке Сибирской платформы относятся к 1744 г и принадлежат академику И. Г. Гмелину, который в 1736 г изучил выходы бурого угля на Сургуевом камене (старое название ныне действующего Кангаласского месторождения в пределах одноименного утеса [2]). Как следует из последующих публикаций [3 и др.], новый этап сводного мелкомасштабного картографирования территории РФ преследовал главную цель - в короткий период освоения дать на территорию Якутии Геологическую карту масштаба 1:500 000 (рис. 1), составленную в виде комплектов (блоков) на базовой основе Госгеолкарт-200 и, существующих на это время, карт разного геологического содержания. Эти комплекты должны были выступать как новейшая геологическая основа и являться основным источником фундаментальной геологической информации в ходе решения разнообразных вопросов изучения и использования недр. Однако с начала 2000-х годов, резко изменилось планирование и целевое финансирование ГРР и, на повестку дня МПР России вышло новое приоритетное направление в картографическом изучении территорий РФ. В ходе реализации рекомендаций МПР России, на востоке Сибирской платформы и на перспективных участках зоны перехода «Сибирская платформа - Верхояно-Колымская складчатая область», начало проводиться Государственное мелкомасштабное картографирование масштаба 1:1 $000000[4,5]$. Это картографирование продолжается и ныне.

\section{Изученность и некоторые комментарии к ней}

В ходе выполнения Государственного мелкомасштабного картографирования на востоке платформы и в «зоне перехода», с некоторой степенью условности, - установлено $[4,5]$, что по возрасту выделяются четыре этапа проявления магматической деятельности: раннепротерозойский (эекитский гранитовый комплекс), позднепротерозойский (среднерифейский уэттяхский долеритовый; вендский монгусский трахибазальт-трахитовый комплексы), среднепалеозойский (среднепалеозойский молодо-уджинский долеритовый; позднедевонско-раннекаменноугольный толуопско-мерчимденский кимберлитовый комплексы) и мезозойский (раннетриасовый молодинский долеритовый; позднеюрские хорбусуонский и куойкскомолодинский кимберлитовые комплексы). Позднеюрские комплексы (хорбусуонский и куойкско-молодинский) располагаются вдоль северного и северовосточного обрамления платформы и обладают здесь, в конечном счете, реальными перспективами для образования потенциально промышленных объектов коренных источников алмаза. Следует отметить, что возраст пород куойкско-молодинского комплекса остаётся на сегодня еще дискуссионным и, в основном, определяется с учетом как изотопно-геохронологических, так и палеонтологических данных.

Так как кимберлитовые тела в Куойкско-Молодинском поле залегают среди отложений венда, кембрия, перми, в нижнетриасовых вулканитах молодинской толщи и раннетриасовых силлах долеритов молодинского комплекса, определение их возраста бывает затруднительным. И здесь, большое подспорье оказывают палеонтологические и палеоботанические остатки. Так, из ксенолитов трубки Обнажённая были извлечены и определены ростры юрско-меловых белемнитов Pachyteuthis (Acroteuthis) sp. (cf. Subrectangulata Bliithg.), а в трубках Заозерная, Хризолитовая, Маричка и Гранатовая установлены методами палеоботанического анализа остатки споры и пыльцы. Среди этих остатков чаще превалируют типично юрские и нижнемеловые формы. Поэтому возрастное датирование некоторых тел комплекса было проведено с учетом палеонтологических и палеоботанических данных, при этом приоритет был отдан позднеюрскому-раннемеловому времени их формирования.

В пределах востока Сибирской платформы, а также в «зоне перехода», формирование магматических образований, по всей вероятности, также происходило в течение длительного периода геологической истории. Скорее всего, мезозойский этап тектоно-магматической активизации, повсеместно имеет общие черты своего развития и проявил себя синхронно вдоль северного, северо-восточного и восточного обрамления платформы.

Возможно, на этом площадном отрезке платформы, проявление очагов магматической деятельности является пространственно взаимосвязанным и, скорее всего, эта деятельность также как и на севере и северо-востоке платформы, начинается с вулканических лавовых излияний умеренно щелочного среднеосновного состава и завершаться проявлениями экструзивно-жерлового вулканизма (т.е. - основными телами трубочного типа, сменившимися, позднее, кимберлитовым вулканизмом). Учитывая выявленные особенности мезозойского кимберлитового магматизма на севере и северо-востоке Сибирской платформы, можно предположить, что подобный характер его проявления, можно ожидать и в пределах Вилюйской синеклизы.

\section{Постановка проблемы}

Восток Сибирской платформы неравномерно изучен в плане перспектив коренной и россыпной алмазоносности. Не является исключением Вилюйская 


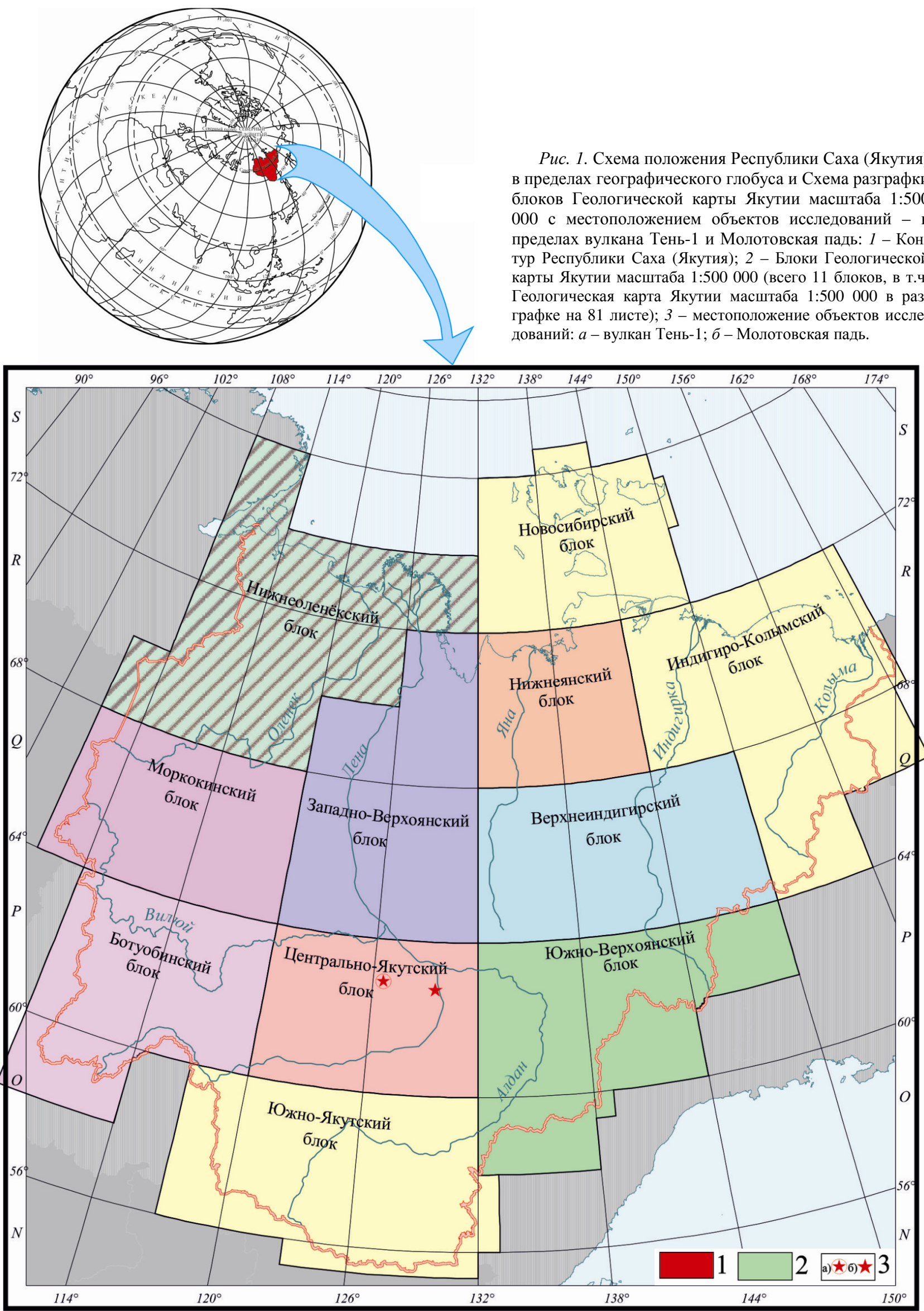


синеклиза - крупнейшая отрицательная структура I порядка древней платформы, охватывающая в районе Большого Якутска бассейн р. Лена [6]. В пределах Вилюйской синеклизы, в её юго-восточной бортовой зоне, известны находки пиропов и пикроильменитов, которые являются индикаторными минералами кимберлитов [7]. Это очень важная находка, так как само её местоположение (бассейн р. Кенкеме, к западу от Большого Якутска), определяет, с поисковой точки зрения, и перспективу самого объекта исследований, который, по предварительным геологическим предпосылкам, располагается в поле развития как позднемезозойских (юрских и меловых), так и более молодых, кайнозойских образований. Также в данной работе указывается, что обозначенная ассоциация индикаторных минералов кимберлитов имеет высокую степень износа минералов, что позволяет обозначить и генезис их прохождения (через прибрежно-морские условия седиментогенеза). Следовательно, индикаторные минералы кимберлитов поступали в речной аллювий р. Кенкеме из древних промежуточных морских коллекторов. Резюмируя доступные для анализа материалы по россыпной алмазоносности востока Сибирской платформы и оценивая имеющуюся на сегодня геологическую информацию, изложенную в работе [8, рис. 1], в т.ч., и по выявленным особенностям проявлений мезозойского кимберлитового магматизма [5, 9, 10 и др.], можно заключить, что наиболее вероятными, в данном случае, коллекторами морского генезиса, могли являться различные временные уровни позднеюрских (оксфорд-волжских) отложений, непосредственно расположенных на южном борту Вилюйской синеклизы. При этом поступление в морской бассейн минералов-спутников алмаза происходило, по всей вероятности, непосредственно в ходе дезинтеграции кимберлитовых тел при их размыве. Изложенное позволяет, в перспективе, ожидать постановку поисковых работ на алмазы, как в пределах Большого Якутска, так и в его западных окрестностях, учитывая естественные этапы развития юрских морских [11] и меловых континентальных [12] осадочных бассейнов Восточной Сибири. Поэтому, для оптимизации поисков различных типов минерального сырья в пределах юго-восточной бортовой зоны Вилюйской синеклизы, необходимо постоянно совершенствовать стратиграфическую основу и палеогеографические реконструкции рассматриваемого интервала. Это и является на сегодня основной нашей задачей.

\section{Результаты исследований}

Следует подчеркнуть, что юрские и меловые осадочные образования лаптевского $\left(\mathrm{T}_{3} \mathrm{r}_{2}-\mathrm{J}_{3} \mathrm{v}\right)$ и китчанского $\left(\mathrm{K}_{1} \mathrm{~b}-\mathrm{K}_{1} \mathrm{al}_{1}\right)$ подкомплексов верхоянского терригенного комплекса (ВТК) довольно детально изучены по многочисленным (более 200) естественным разрезам в зоне перехода «Сибирская платформа - Верхояно-Колымская складчатая область» [8, 13, 14]. Эти разрезы тяготеют, преимущественно, к востоку Сибирской платформы (рр. Вилюй, Лена, Амга, Алдан).
Они также многочисленны в её складчатом обрамлении (бассейны рек Ундюлюнг, Кюндюдей, Дянышка, Леписке, Чочума, Тумара, Белянка, Келе, Барайы, Байбыкан, Тукулан, Томпорук, Восточная Хандыга, Томпо, Сугджа и др.). Корреляция разрезов осадочных геологических тел выполнена с использованием литолого-стратиграфического, палеонтологического и палеоботанического методов [6, 8]. В ходе изучения юрских и меловых пород реперные литологические горизонты в отдельных скважинах прослежены на закрытых территориях - в глубоких горизонтах осадочного чехла Вилюйской синеклизы, Алданской антеклизы и Предверхоянского краевого прогиба, с использованием промысловых геолого-геофизических данных. К изучению был привлечен и керн из стволов картировочных колонковых и опорных разведочных скважин на нефть и газ, который, как объект изучения, характеризовал небольшие по мощности, продуктивные на полезные ископаемые горизонты. Возрастное датирование геологических тел юры и мела и их порайонная стратификация проведена с использованием региональных стратиграфических и фитостратиграфических горизонтов Сибири. Это позволило довольно детально охарактеризовать литологический разнородный керновый материал и, выявить, в целом, объемную палеонтолого-стратиграфическую и палеоботаническую характеристику изученного юрскомелового интервала. Исследования опирались, в большинстве своем, на обобщающие работы, в т.ч., на мелкомасштабные карты и схемы разного геологического содержания, а для целей корреляции разрезов в Вилюйской синеклизе и в «зоне перехода», использовались доступные публикации открытой печати [2, 12, 15-20 и др.]. Фактически, исследования преследовали цель комплексной ревизии разреза юры и мела верхоянского терригенного комплекса в «зоне перехода». Эта ревизия касалась, в основном, доизучения пограничных слоев поздней юры и раннего мела, уточнения объема ВТК в пределах позднеюрского-раннемелового (лаптевский-китчанский подкомплексы) временных интервалов.

В юрскую и меловую эпохи на востоке Сибирской платформы и в ее складчатом обрамлении проявили себя ряд стадий тектоно-магматической активизации, обусловленных биотическими и абиотическими событиями. Так, в «зоне перехода» были установлены в позднетриасовое - юрское время три тектоно-седиментологические стадии формирования лаптевского подкомплекса $\left(\mathrm{T}_{3} \mathrm{r}_{2}-\mathrm{J}_{3} \mathrm{v}\right)$ : ранняя $\left(\mathrm{T}_{3} \mathrm{r}_{2}-\mathrm{J}_{1}\right)$, промежуточная $\left(\mathrm{J}_{1-2}\right)$ и поздняя $\left(\mathrm{J}_{2-3}\right)$, соответствующие (соответственно) древнекиммерийской, данлапской и новокиммерийской глобальным стадиям тектоно-магматической активизации [13]. Глобальный уровень новокиммерийской стадии тектоно-магматической активизации на Сибирской платформе маркирован на её северо-востоке - хорбосуонским $\left(\mathrm{J}_{2-3} h b\right)$ и куойкскомолодинским $\left(\mathrm{J}_{3} \mathrm{~km}\right)$ комплексами кимберлитового магматизма (поздняя $\left(\mathrm{J}_{2-3}\right)$ стадия формирования лаптевского подкомплекса) [21 и др.]. На востоке Сибир- 
ской платформы, в Вилюйской синеклизе, в коренном осадочном терригенном континентальном разрезе верхней юры, на границе с континентальным терригенным нижним мелом, впервые в практике тематических и геолого-съемочных работ диагностированы вулканогенные и вулканогенно-осадочные породы. Пограничные осадочные образования верхней юры и, непосредственно, нижнего мела в разрезе (коренной выход в северной части долины «Туймада», в 26 км севернее г. Якутска, «Молотовская падь», терраса левого берега р. Лена, 62²5'С.Ш., 12907'В.Д.) представлены (снизу вверх) слоями, которые соответствуют бергеинской и батылыхской свитам. В состав этих геологических тел входят пески, песчаники, угли каменные, литокристаллокластические туфы, лавы дацитов. В литокристаллокластических туфах авторами выполнены сборы листовой флоры (табл. 1), характерной для бергеинской свиты бассейна р. Алдан (определения выполнены А.И. Киричковой). Найденная флора впервые характеризует кровлю коренного разреза позднеюрской бергеинской свиты Большого Якутска. Она маркирует вулканогенные породы поздней юры непосредственно на границе с ранним мелом. В зоне перехода «Сибирская платформа - Верхояно-Колымская складчатая область» новый разрез кровли юры с вулканогенными породами скоррелирован среди опорных терригенных верхнеюрских разрезов платформы на основе фитостратиграфических горизонтов Сибири.

Бергеинская свита $\left(\mathrm{J}_{3} b r\right)$ (урез воды, абс. отм. 98 м). Описание разреза в карьере на абс. высоте 120 м). Здесь вскрыты (снизу вверх):

1. Песчаники серые и светло-серые мелкосреднезернистые континентального генезиса, видимая мощность, 3,0 м.

2. Лавы дацитов. Аз. пад. $150^{\circ} \angle 78-85^{\circ}$, видимая мощность, 2,0 м.

3. Туфы красные, красно-бурые литокристаллокластические. Аз. пад. $22^{\circ} \angle 7-8^{\circ}$. Остатки флоры: Equsetites cf. acmophyllus Kiritch, Equsetites sp., Cladophlebis aldanensis Vachr., Raphaelia cf. kirinae Kiritch., фрагменты: Nilssonia, Czekanowskia, Cycadales, Coniferales, видимая мощность, 1,5 м.

Полученный комплекс растений является позднеюрским по наличию хорошей сохранности листовой флоры: фрагменты перьев характерного для этого возрастного уровня Cladophlebis aldanensis Vachr., побеги хвощовых, хотя и определенных со знаком cf. На территории Вилюйской синеклизы эти формы листовой флоры неоднократно встречены в бергеинской свите. Выше по разрезу флора Cladophlebis aldanensis Vachr. не известна на востоке Сибирской платформы (бассейны pр. Вилюй, Лена, Амга и Алдан).

4. Угли черные и бурые каменные, видимая мощность $0,5 \mathrm{M}$.

5. Пески рыхлые светло-серые и серые разнозернистые, песчаники серые и светло-серые мелкосреднезернистые, видимая мощность, 5,0 м.

6. Задерновано, залесено, видимая мощность, 16,0 м.
Кровля бергеинской свиты. Общая видимая мощность бергеинской свиты в разрезе составляет $28,0 \mathrm{M}$.

Батыльхская свита $\left(\mathrm{K}_{1} b t\right)$. Описание нижнего мела произведено на абс. высоте 148 м (снизу вверх):

7. Пески светло-серые и серые, песчаники серые и светло-серые мелко- и среднезернистые плитчатые и комковато-плитчатые, чаще в развалах и реже в полукоренных выходах. Аз. пад. $22^{\circ} \angle 7^{\circ}$, видимая мощность 2,5-3,0 м.

Остатки флоры (табл. 2) цикадовых и беннеттитовых (сборы листовой флоры проведены авторами, определения выполнены А. И. Киричковой). Впервые охарактеризован одновременно цикадовыми, беннеттитовыми и хвойными коренной разрез подошвы нижнего мела в районе Большого Якутска). Тип рода Encephalartites; остатки хвойных, тип рода Sciadopitys. В юрско-меловой флоре Якутии растения этих родов наиболее часты в составе батылыхской свиты раннемеловых тафофлор бассейнов рр. Алдана и Вилюя.

Общая мощность описанного разреза верхней юры и нижнего мела составляет 31,0 м. Отметим, что образцы листовой флоры, приведенные в данной работе по верхней юре и нижнему мелу, по предложению А. И. Киричковой, переданы в феврале 2018 г на хранение в Отдел палеоботаники Ботанического института РАН (г. Санкт-Петербург).

В меловую эпоху уровни абиотического и флористического событий были также зафиксированы в Вилюйской синеклизе. Так, в бассейне р. Лена (верховья р. Лунгха), абиотическое событие проявило себя в батылыхское время нижнего мела [10, 22]. Нижнемеловое хатырыкское событие выявлено в ряде пунктов Вилюйской синеклизы: на р. Ситте (10 м пласт туфов, маркированных листовой флорой хатырыкского горизонта); в Намской опорной скважине (пласт 4 м гранодиоритовых туфов в основании хатырыкской свиты); на р. Чыбыда, в пласте песка выявлено высокое содержание вулканического стекла в основании хатырыкской свиты; в скважинах № 7 и № 9 Вилюйского колонкового профиля в нижнемеловых породах хатырыкской свиты установлены вулканические пеплы [14, 23, 24].

Наличие в разрезах разных бассейнов рек Вилюйской синеклизы значительно изменчивой мощности нижнемеловых отложений говорит о тектонической активности территории в этот временной интервал. В этой связи, находки туфогенных пород, их выдержанная латеральная позиция в разрезе, не только указывают на тектоническую перестройку на территории Вилюйской синеклизы в конце нижнемеловой эпохи (кровля китчанского подкомплекса ВТК; хатырыкский рубеж), но и свидетельствует, что эти процессы были интенсивными на значительных пространствах востока Сибирской платформы и также сопровождались вулканизмом, как мы это наблюдали на рубеже верхней юры и нижнего мела в районе Большого Якутска. 

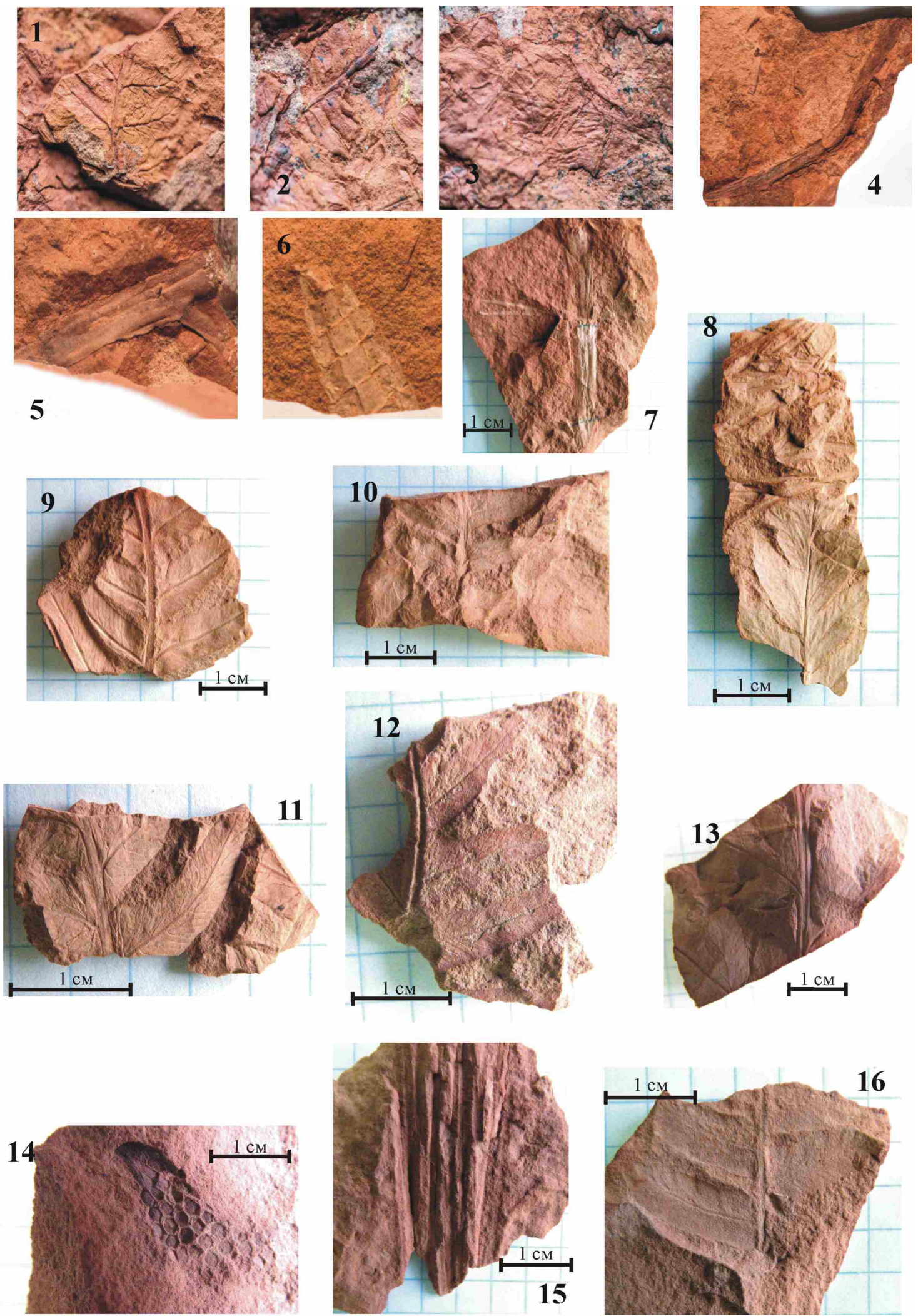

Таблица 1. Позднеюрская флора (Молотовская падь, район Большого Якутска, покров туфов и туфопесчаников, абс. высота 120 м): 1-3 - папоротники Cladophlebis - C. cf. aldanenis Vachrameev; Nilssonia ?; 4-5 - побеги хвощового Equisetites cf. acmophyllus Kiritch., Equisetites sp., Czekanowskia?; 6 - отпечаток мегастробила цикадового Cycadales?; 7 - побеги хвощевого Equisetites cf. acmophyllus Kiritch.; 8-12 - папоротники Cladophlebis aldanensis Vachr.; 13 - фрагмент пера папоротника Raphaelia cf. kirinae Kiritch.; 14 - отпечаток мегастробила хвойного Coniferales?; 15 - пучок узких дихотомирующих листьев Czekanowskia ?; 16 - фрагмент перьев папоротника Cladophlebis aldanensis Vachr. Возрастное датирование флоры - поздняя юра. Папоротники 1-3, 8-12 характерны для отложений верхней юры (бергеинская свита $\mathrm{J}_{3} b r$ ) Ленского бассейна и позднеюрских отложений бассейна Буреи. 

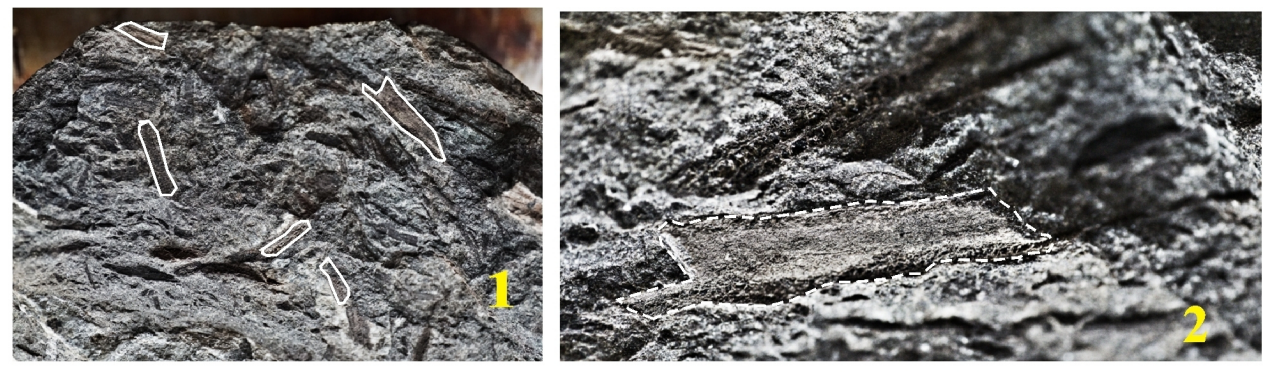

A
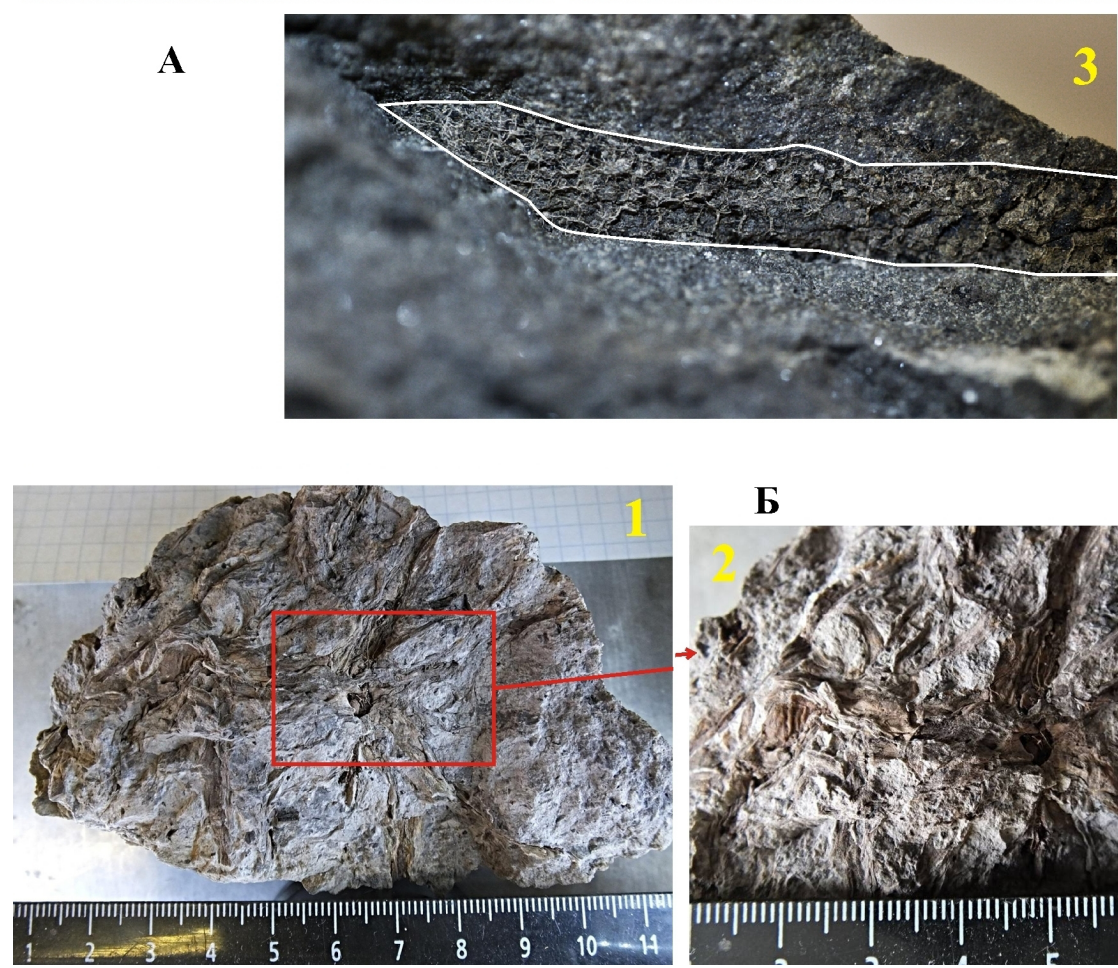

Б

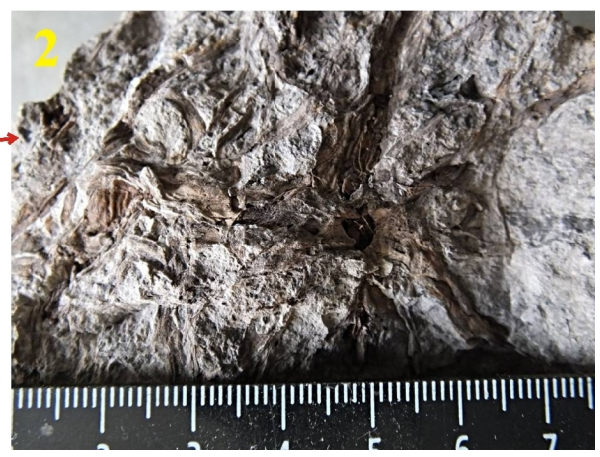

Таблица 2. Раннемеловая флора ( $A$ - вулкан Тень-1 и $E$ - Молотовская падь, район Большого Якутска).

$A$ - Вулкан Тень-1: геологическая точка № 5, обр. флоры № 1029 из лавового потока. 1 - многочисленные остатки флоры папоротников: фрагменты сильно смятых узких линейных листьев хвойных типа Pityophyllum и, возможно, узких сегментов листьев гинкговых (дацитовый туф из лавового потока-1 вулкана Тень-01); 2 - побег хвощовых; 3 - побег хвойных. Листья хвойных обведены сплошной белой линией, побег хвощовых - пунктирной. Возрастное датирование папоротников из обр. № 1029 - ранний мел (батылыхская свита $\left.\mathrm{K}_{1} b t\right)$.

$Б$ - Молотовская падь, район Большого Якутска: геологическая точка № 4. Обр. флоры № 1046 из песчаников раннего мела (абс. высота 148 м). 1, 2 - цикадовые и беннеттитовые типы рода Encephalartites (близкий к современному роду Encephalartos) и хвойным - род Sciadopitys. Возрастное датирование флоры из песчаников, обр. 1046 - ранний мел. В юрско-меловой флоре Якутии растения этих групп присутствуют, но наиболее часты они в составе раннемеловых тафофлор (батылыхская свита, $\mathrm{K}_{1} b t$ ), в частности, остатки флоры характерны для бассейнов Алдана и Вилюя.

\section{Выводы}

1. В Вилюйской синеклизе, на границе лаптевского и китчанского подкомплексов верхоянского терригенного комплекса, установлен новый тип разреза переходных слоев от поздней юры к раннему мелу. Уровни вулканической деятельности (поздняя юра волжское время), ранний мел (хатырыкское время) являются глобальными событийными рубежами. Эти события маркированы новыми флористическими остатками. Подтверждены выявленные ранее региональные стратиграфические и фитостратиграфические горизонты Сибири, которые тесно связаны с глобальным проявлением позднеюрской-раннемеловой тектоно-магматической активизации на Северо-Востоке Азии. В рамках рубежей этой активизации на севере, северо-востоке и востоке Сибирской платформы, в пределах Якутской кимберлитовой провинции, синхронно проявил себя позднеюрский-раннемеловой алмазоносный кимберлитовый магматизм.

2. Изложенные результаты имеют определяющее значение для решения ключевых вопросов возрастного расчленения, датирования местных подразделений (осадочные и вулканогенно-осадочные образования) юры и мела, их порайонной и межрайонной корреляции, повышения достоверности палеогеографических реконструкций и усиления степени надежности минерагенического прогноза «зоны перехода» на стратегически значимые полезные ископаемые: алмазы, благородные металлы, концентрированные углеводороды, каустобиолиты и др. 
Исследование выполнено в соответствии с планом НИР ИГАБМ СО РАН на 2018 г. в рамках Проектов № 0381-2016-0001 и 0381-2016-0004.

\section{ЛИТЕРАТУРА}

1. Геологическая карта Якутии масштаба 1:500 000. Объяснительная записка (Методика составления) / В. А. Ян-Жин-Шин [и др.] // Якутск: Отпечатано на Санкт-Петербургской картфабрике ВСЕГЕИ, 2001. - 26 с.

2. Мишнин, В. М. Третий геолого-промышленный тип концентрированного оруденения Якутского погребенного поднятия: ретроспективный взгляд / В. М. Мишнин, В. С. Гриненко, А. П. Андреев // Наука и образование. - 2013. - № 4 (72). - С. 18-24. 3. Новый этап картографирования территории Якутии / В. А. Ян-Жин-Шин [и др.] // Отечественная геология. -1994. - № 8. C. 25-27.

4. Геологическая карта. Q-52 (Верхоянские цепи). ВерхояноКолымская серия / В. С. Гриненко [и др.] // Государственная геологическая карта РФ масштаба 1:1 000000 (третье поколение). СПб.: Санкт-Петербургская картфабрика ВСЕГЕИ, 2008.

5. Геологическая карта. R-51 (Джарджан). Анабаро-Вилюйская серия / В. С. Гриненко [и др.] // Государственная геологическая карта РФ масштаба 1:1 000000 (третье поколение). СПб.: Санкт-Петербургская картфабрика ВСЕГЕИ, 2013.

6. Геологическое строение Большого Якутска / В.С. Гриненко [и др.] // Региональная геология Якутии: сборник научных статей. Якутск: Изд-во ЯГУ. - 1995. - С. 3-20.

7. Перспективы алмазоносности южного борта Вилюйской синеклизы / Афанасьев В. П. [и др.] // Отечественная геология. - 2007. - № 1. - С. 119-122.

8. Геологическая карта Якутии масштаба 1:500 000. Центрально-Якутский блок. Листы: Р-51-А,Б; Р-51-В,Г; Р-52-А,Б; Р-52В,Г / В. С. Гриненко [и др.] // СПб.: Санкт-Петербургская картфабрика ВСЕГЕИ, 2000.

9. Гриненко, В. С. Позднеюрское и раннемеловое биотическое и абиотическое события Вилюйской синеклизы (восток Сибирской платформы) / В. С. Гриненко, А. В. Костин, М. С. Желонкина // Геология и минерально-сырьевые ресурсы Северо-Востока России: материалы VIII Всероссийской научно-практ. конференции, 18-20 апреля 2018 г. в 2 т. - Якутск: Изд-во Института мерзлотоведения им. П. М. Мельникова СО РАН, 2018. - Т. 2. - С. 55-60. 10. Костин, А. В. Первые данные о проявлении верхнемелового вулканизма зоны перехода «Сибирская платформа - ВерхояноКолымская складчатая область» / Костин А. В. [и др.] // Наука и образование. - 2015. - № 1 (77). - С. 30-36.

11. О характере границы нижней-средней юры в зоне сочленения Сибирской платформа - Верхоянский складчато-надвиговый пояс / В. С. Гриненко [и др.] // Отечественная геология. 2015. - № 5. - C. 83-89.

12. Гриненко, В. С. Меловые континентальные образования востока Сибирской платформы / В. С. Гриненко // Отечественная геология. - 2007. - № 1. - С. 110-118.

\section{ФГБУН ИГАБМ СО РАН, г. Якутск}

Гриненко Виталий Семенович, ст. науч. сотрудник, к.г.-м.н. E-mail: grinenkovs@diamond.ysn.ru; grinenkovs52@mail.ru Тел.: 8-914-299-46-58

Костин Алексей Валентинович,зав. лабораторией, гл. науч. сотрудник, д.г.-м.н. E-mail: kostin@diamond.ysn.ru; a.v.kostin2006@rambler.ru; Тел.: 8-914-226-23-70

Желонкина Мария Сергеевна, ведущий инженер E-mail: greysvandir@mail.ru; Тел.: 8-914-263-78-25

\section{ФГУП «ВНИГРИ», г. Санкт-Петербург}

Киричкова Анна Ивановна, гл. науч. сотрудник отдела стратиграфии нефтегазоносных провиниий, д.г.-м.н., профессор E-mail: kirichkovaanna@gmail.ru; Тел. 8-(812)400-08-38
13. Гриненко, В. С. Лаптевский подкомплекс $\left(\mathrm{T}_{3} \mathrm{r}_{2}-\mathrm{J}_{3} \mathrm{~V}\right)$ верхоянского терригенного комплекса / В. С. Гриненко, В. Г. Князев // Наука и образование. - 2012. - № 4 (68). - С. 13-18.

14. Гриненко, В. С. Китчанский $\left(\mathrm{K}_{1} \mathrm{~b}-\mathrm{K}_{1} \mathrm{al}_{1}\right)$ подкомплекс новое подразделение верхоянского терригенного комплекса (зона перехода «Сибирская платформа - Верхояно-Колымская складчатая область) / В. С. Гриненко, В. П. Девятов // Наука и образование. - 2017. - № 1 (85). - С. 33-40.

15. Гриненко, В. С. Разрезы юры и мела бассейнов рек Леписке и Чечума как отражение этапности осадко-, угленакопления и развития флоры в позднем мезозое (Восточная Якутия) / В. С. Гриненко / Проблемы стратиграфии и палеогеографии бореального мезозоя. Новосибирск: Изд-во СО РАН, Филиал «Гео». 2001. - C. 32-34.

16. Гриненко, В. С. Стратиграфия юрских отложений Хапчагайского и Лено-Вилюйского районов: расчленение и межрегиональная корреляция / В. С. Гриненко, В. Г. Князев // Отечественная геология. - 2008. - № 5. - С. 72-78.

17. Киричкова, А. И. Нижнемеловые отложения низовьев р. Лены (Булунский район) / А. И. Киричкова, В. Н. Зинченко, С. А. Чирва // Геология и геофизика. - 1987. - № 4. - С. 21-29.

18. Региональная стратиграфическая схема юрских отложений Восточной Якутии / В. Г. Князев [и др.] // Отечественная геология. - 2002. - № 4. - С. 73-80.

19. Новые данные по стратиграфии морских юрских отложений Лено-Алданского междуречья / Ю. Л. Сластенов [и др.] // Геология и геофизика. - 1989. - № 11. - С. 139-142.

20. Стратиграфия юры Восточной Сибири (состояние изученности, основные проблемы и способы их решения) / Б. Н. Шурыгин [и др.] // Вестник Госкомгеологии. Материалы по геологии и полезным ископаемым Республики Саха (Якутия). Якутск: Якутский филиал издательства СО РАН. - 2001. - № 1. - С. 112-129.

21. Новые данные о стратиграфии верхнетриасовых-юрских отложений перспективных на алмазы восточных районов Сибирской платформы / В. С. Гриненко [и др.] // Наука и образование. - 2009. - № 4. - С. 21-30.

22. Тюгенинское вулканическое поле - новый геологический объект востока Сибирской платформы / А. В. Костин [и др.] // Геология и минерально-сырьевые ресурсы Северо-Востока России: материалы Всероссийской научно-практической конференции, 6-8 апреля 2016 г. отв. ред. Л. И. Полуфунтикова. Якутск: Издательский дом СВФУ. - 2016. - С. 380-383.

23. Гольбрайх, И. Г. О находке туфогенных пород в нижнемеловых отложениях бассейна р. Ситте (левый приток р. Лены). / И. Г. Гольбрайх, В. Н. Тодоровская // Геология и нефтегазоносность Западной Якутии: Труды ВНИГРИ. Вып. 249. Л.: Недра, 1966. - С. 182-185.

24. Киричкова, А. И. Новые меловые папоротники севера Сибири / А. И. Киричкова, В. В. Павлов // Палеонтологический журнал. - 1965. №2. - С. 118-121.

\section{FGBUN SBRAS IGABM, Yakutsk}

Grinenko V. S., PhD, Chef of Sciences, Laboratories Geodynamics and Regional Geology.E-mail:grinenkovs@diamond.ysn.ru; grinenkovs52@mail.ru; Tel.: 8-914-299-46-58

Kostin A. V., Dr. of Sciences, Laboratories head Precious Metals Geology and Mineralogy.E-mail: kostin@diamond.ysn.ru; a.v.kostin2006@rambler.ru; Tel.: 8-914-226-23-70

Zhelonkina M. S., management engineer, Laboratories Precious Metals Geology and Mineralogy.E-mail: greysvandir@mail.ru

FGUP VNIGRI, St.-Petersburg

Kirichkova A. I., Dr. of Sciences, Professor, Laboratories stratigraphy of the Oil and Gas provinces

E-mail: kirichkovaanna@gmail.ru; Tel. 8-(812) 400-08-38 